\title{
Ekoköylerin Kent Ölçeğinde Uygulanabilirliği Üzerine Bir Araştırma
}

\author{
Osman ZEYBEK ${ }^{* 1}$ (D) Mükerrem ARSLAN ${ }^{2}$ (D) \\ ${ }^{1}$ Bursa Uludağ Üniversitesi Ziraat Fakültesi Peyzaj Mimarlığı Bölümü, 16059, Bursa \\ ${ }^{2}$ Ankara Üniversitesi Ziraat Fakültesi Peyzaj Mimarlığı Bölümü, 06120, Ankara
}

Öz: Gün geçtikçe ünlenen ve çoğunlukla bireysel - komünal girişimler olmasına rağmen devletlerin de ilgisini çekmeye başlayan ekoköyler, çoğu araştırmacı tarafından dünyanın bozulan dengesini onarmak için en umut vadeden hareket olarak görülmektedir. Çok farklı iklimlerde ve topografyalarda kurulabilen ekoköylerin temel amacı, bulundukları yerde en düşük ekolojik ayak iziyle yaşamayı deneyimlemek ve bunu daha da düşürmenin yollarını aramaktır. Ekolojik ayak izi hesaplamalarında kullanılan temel parametrelerden biri, kişi başına düşen verimli ıslak ve karasal alanlardır. Bu çalışmada, daha net karşılaştırmalar yapabilmek için dünyanın çeşitli yerlerinden, farklı şekillerde tasarlanmış ekoköyler incelenmiştir. Sahip oldukları nüfus, verimli ıslak ve karasal alanlar hesaplanarak kişi başına düşen alanlar belirlenmiştir. Elde edilen sonuçlar, dünyanın nüfusuyla karşılaştırılarak teorik sonuçlar tartışılmıştır.

Anahtar Kelimeler: ekoköy, ekoköy hareketi, sürdürülebilir yerleşkeler, sürdürülebilir toplumlar

\section{A Research on the Applicability of Ecovillages at City Scale}

\begin{abstract}
That ecovillages, getting more popular day by day and the calling attention of governments in spite of they are individual communal initiatives, are seen as the most promising movement to fix unbalanced world by many researchers. The main purpose of ecovillages that can be set up in many different climates and topographies is to experience living with the lowest ecological footprint and looking for ways to lower it on and on. One of the basic parameters used in ecological footprint calculations is the fertile wetlands and terrestrial areas per capita. In this study, echoes designed in different ways from different parts of the world have been examined in order to make clear comparisons. Per capita areas were determined by calculating their population, fertile wetlands and terrestrial areas. The results are compared with the population of the world and the theoretical results are discussed.
\end{abstract}

Keywords: ecovillage, ecovillage movement, sustainable settlements, sustainable communities

\section{GiRiş}

Küresel ısınmanın hızlandırdığı, günümüzde daha da ciddileşen bir sorun haline gelen iklim değişikliği, yaşam tarzımızı sorgulatan en önemli etmenlerden biri olarak gün yüzüne çıkmıştır. Birkaç on yıl öncesine dek, geniş çaplı küresel ve bölgesel iklim değişikliklerinin yüzlerce ya da binlerce yıllık bir zaman ölçeği içerisinde kademeli olarak gerçekleştiği düşünülür ve bu nedenle, iklim kaymalarının bir insan ömrü içinde algılanamayacağı varsayılırdı. İklimin insan tarihi boyunca birdenbire değişme eğilimi göstermiş olması, geçmiş dönemlerdeki iklimlerle ilgili çalışmaların en şaşırtıcı sonuçlarından biri olmuştur. En şiddetli iklim değişikliklerinden bazılarının birkaç on yıl, hatta yalnızca birkaç yıl içinde yıllık ortalama sıcaklıklarda 5으 düzeyine varan bölgesel değişiklikler içerdiği yönünde reddedilemez kanıtlar bulunmaktadır. IPCC 2001 raporunun tahminine göre, 2100 yılına gelindiğinde küresel ortalama yüzey sıcaklığı 1,4 ila $5,8 \circ \mathrm{C}$ arasında yükselebilir ve bu da, 2100 yılına gelindiğinde küresel ortalama deniz seviyesinin 20 ila $88 \mathrm{~cm}$ arasında yükselmesi anlamına gelir. Gelecekte yaşanacak iklim değişikliği kıyı bölgeleri, fırtına ve seller, sağıı ve su kaynakları, tarım ve biyolojik çeşitlilik gibi, insan toplumunu etkileyen tüm unsurlar üzerinde etkili olacaktır. İklim değişikliği bir toplum üzerinde harici bir baskı oluşturur, ama toplumun ayakta kalıp kalamayacağını kendi yapısı, özellikle de esneklik düzeyi belirler (Maslin 2011).
Küresel ısınma sorununa en mantıklı yaklaşım, salımları önemli düzeyde azaltmak gibi görünmektedir. Bilim adamları küresel ısınmayı yalnızca bir derece düzeyiyle sınırlayabilmek için (\%60'a ulaşabilen) önemli düzeyde bir kesinti yapılması gerektiğini savunmaktadır. Ancak böyle bir kesintinin dünya ekonomisi üzerinde çok önemli etkileri olacaktır ve iklim değişikliğinin neden olabileceği hasara kıyasla salımları kısmanın maliyeti son derece tartışmalı bir konudur. Devletlerin karbondioksit salımını azaltmak için yavaş yavaş harekete geçmeye başladıkları bilinmektedir, ancak bunun ne kadara mal olacağı, ekonomistleri kaygılandırmaktadır. Dolayısıyla küresel ısınma sorununun çözümü için alternatiflere ya da teknik çözümlere büyük ilgi gösterilmektedir.

Jackson'a (2004) göre, bireylerin kendi hayatlarında deneyimlediği çevre sorunlarının ciddiyetinin farkına varmaları da bilinçli topluluklara yönelik ilgiyi arttırmıştır. Hükümetlerin ekolojik krizleri sistemli bir şekilde ele alma konusundaki başarısızlıkları, birçok insanın mevcut gidişatın içeriden düzeltilemeyecek kadar temelden hatalı olduğu sonucuna varmasına neden olmuştur.

Sorumlu Yazar: osmanzeybek@uludaq.edu.tr Bu çalışma yüksek lisans tez ürünüdür.

Geliş Tarihi: 13 Şubat 2019

Kabul Tarihi: 4 Aralık 2019 
Hannover Üniversitesi'nden Prof. Dr. Robert J. Rosenthal "Ekoköyler, yeni ve gelecek için ümit veren, belli bir amaç ile bir araya gelmiş, bilinçli topluluklardır. Yapılarında iki önemli özelliği barındırırlar. Birincisi, en nitelikli yaşamın insanların birbirini desteklediği, sağlıklı küçük topluluklarda oluştuğudur. İkincisi ise, insanlık için sürdürülebilir yaşam yolunun geleneksel toplum yaşamının tekrar canlandırılmasından geçtiğidir. Ekoköyler, tarih boyunca en fazla ümit veren, en önemli harekettir." diyerek konunun hassasiyetine dikkat çekmiştir (Dawson 2006).

Araştırma ile irdelenmek istenen konu, ekoköylerin taşıma kapasitesinin ne kadar arttırılabileceğini, giderek yoğunlaşan çevre sorunlarının bu yolla ne ölçüde düzeltilebileceğini yorumlamaktır.

\section{MATERYAL VE YÖNTEM}

Ekoköy tanımını daha net algılayabilmek için farklı niteliklere sahip ekoköylere göz gezdirmek gerekmektedir. $\mathrm{Bu}$ gereksinimden yola çıkarak, araştırmanın materyali oluşturulurken dünyanın her kıtasından ve çeşitli bölgelerinden, farklı uygulamaları ve farklı hikâyeleri olan ekoköyler seçilmiştir. Bu bağlamda Asya'dan Auroville Ekoköyü, Avustralya'dan Crystal Waters Ekoköyü, Afrika'dan Basata Ekoköyü, Güney Amerika'dan Ecoovila Ekoköyü, Kuzey Amerika'dan Ithaca Ekoköyü, Avrupa'dan da Findhorn Ekoköyü, Sieben Linden Ekoköyü ve BedZED seçilmiştir.

Incelenmek üzere seçilen ekoköylerle ilgili veri toplama ve literatür taramanın yanı sıra, kişi başına düşen verimli alanları hesaplamak için aritmetik nüfus yoğunluğu hesabı ters çevrilerek kullanılmıştır. Aritmetik nüfus yoğunluğu, bir yerleşim yerinde, belli bir alana düşen kişi sayısının hesaplanmasında kullanılır. Genellikle nüfus artışı ile ilgili araştırmalarda, birim alandaki nüfus yoğunluğunun takip edilmesi ile ilgili araştırmalarda kullanıldığı görülmektedir. Kişi sayısı mevcut alana bölünerek elde edilir. Ekolojik ayak izi hesaplamalarında da kişi başına düşen verimli alanlar hesaplanırken bu işlem ters çevrilir ve alan, mevcut kişi sayısına bölünür. Kullanılan formül aşağıda belirtilmiştir. Sonucun birimi $\mathrm{m}^{2} / 1$ kişi'dir.

$$
\text { Kişi başına düşen alan }=\frac{\text { Köyün alanı }}{\text { Köyün nüfusu }}
$$

Araştırma kapsamında incelenen ekoköylerin güncel nüfusları ve sahip oldukları alan bilgisi yardımıyla kişi başına düşen verimli karasal ve sulak alanları hesaplanmış ve büyüklüklerine göre sıralanmıştır. Kişi başına düşen verimli karasal ve sulak alanların en fazla olduğu ekoköyden elde edilen veriler doğrultusunda, bir kentin nüfus bilgileri esas alınarak, ekolojik ayakizini mevzubahis ekoköyün seviyesine düşürmek için ne kadar alana gereksinim duyulacağı hesaplanmıştır.

\section{BULGULAR}

Farklı kıtalardan, farklı ölçek ve yaşam tarzına sahip ekoköyler seçilerek hem ekoköy olgusunun küreselliği vurgulanmaya çalışılmış, hem de dünya çapında daha genel bir analiz yapılması hedeflenmiştir. İncelenen ekoköylerin tarihine ve genel özelliklerine kısaca değinilmiş, arazi kullanımı ve nüfus bilgilerinin güncel olmasına dikkat edilmiştir.

\section{Auroville}

En başarılı ve tanınmış ekoköylerden Auroville, Güney Hindistan'ın doğu kıyısında, Tamil Nadu eyaletindeki Pondicherry şehri yakınlarında bulunmaktadır. Kuruluşu Hint bilge Sri Aurobindo'nun ruhani partneri olan ve ekoköyde "mother" olarak anılan, Türk bir baba ve Fransız bir annenin çocuğu olan Mira Alfassa'nın bir vizyonu sonucu oluşmuştur. Bu ekoköy kendini "insanların birliğine adanmış ideal bir kasaba denemesi" olarak tanımlamaktadır Auroville'in kurulduğu bölge, başlarda üzerinde hiç bitki örtüsü bulunmayan çorak bir toprak parçasıydı. Hâlihazırda zayıf olan yüzey toprağı, sık sık tekrarlanan fırtına ve muson yağmurlarının oluşturduğu sellerle iyice erozyona uğramış, yağmur suları arkasında derin oyuklar bırakarak platodan denize dökülmüştür. Muson sellerinin yüzeydeki toprağı alıp götürmesini durdurmak için Auroville'in sakinleri ilk iş olarak su bentleri ve sertler yapıp araziyi ağaçlandırmıştır. Kuruluşun ilk zamanlarında bölgede elektrik de mevcut değildi. İlk yerleşenler su pompalaması ve enerji üretmesi için araziye yel değirmenleri kurdu. Topluluk üyeleri biokütle ve güneş enerjisi teknolojilerini geliştirmek için çok çalıştı ve tüm çabalarının sonunda Auroville Hindistan'daki en büyük alternatif enerji sistemleri merkezi haline geldi. Bu alternatif teknolojiler arasında en dikkat çekeni, monte edildiği mutfak çatısından günde 1000 öğün yemek pişirmeye yetecek enerjiyi üretebilen 15 metre çapındaki güneş toplayıcısıdır (Dawson 2006).

Yeniden ağaçlandırma ve yenilenebilir enerji çalışmalarında elde edilen başarıların sonucunda Auroville, 2003 yılında Yeşil Oscar olarak da bilinen Ashden Sürdürülebilir Enerji Ödülü'nü kazanmıştır. Auroville'de kurulan Bilimsel Araştırma Merkezi ise tüm Hint Yarımadası için bir başarı abidesi olarak kabul edilmektedir (Auroville, 2018).

Auroville, günümüzde dünyanın en kalabalık ve en büyük ekoköyüdür. Bir yerleşkeyi dönüştürmek yerine boş bir arazide sıfırdan tasarlanan ekoköyde Şekil 1'deki zonlama sistemi ile 5 bölge belirlenmiştir.

Auroville'in resmi internet sitesinde paylaşılan, 2025 hedeflerini içeren master plana göre, Auroville ekoköyünün arazi büyüklükleri Çizelge 1'deki gibidir. Ekoköyde sürekli yaşayan kişi sayısı 1972'de 320 iken bu sayı 1980'de 676'ya, günümüzde de 1519'a yükselmiştir. Bu nüfusun 570'i 


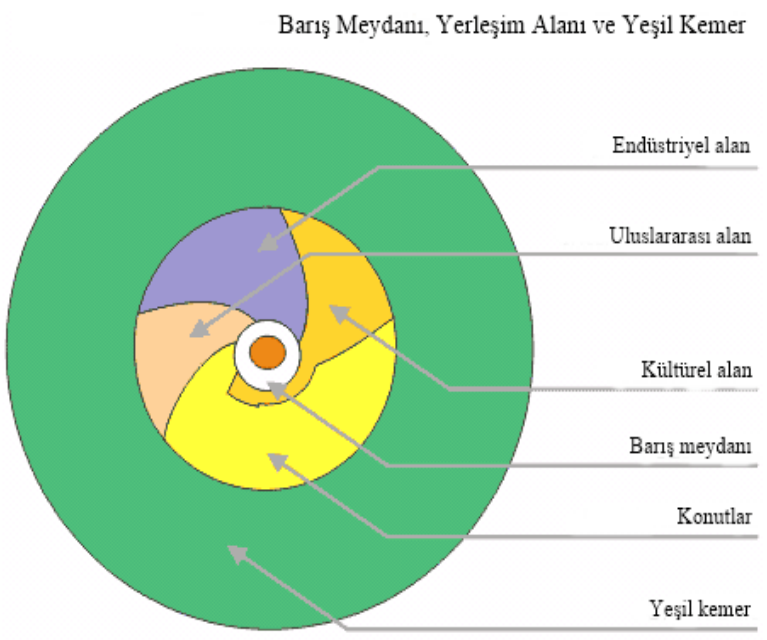

Şekil 1. Auroville'in planı (Auroville, 2018).
Hindistanlılardan oluşmaktayken, 272 kişi Fransız, 230 kişi Alman, geri kalanını da dünyanın pek çok ülkesinden insanlar oluşturmaktadır. Hindistan'ın güney bölgesinde bulunan Auroville, multikültürel yapısıyla UNESCO tarafından "geleceğin evrensel şehri" ilan edilmiştir. Oldukça geniş bir yelpazeye sahip programları vardır ve sürekli ziyaretçi araştırmacılar, üniversite öğrencileri ve uluslararası gönüllüleri ağırlamaktadır. En popüler eğitimler arasında düşük maliyetli bina teknolojisi, sürdürülebilir yaşam, gıda güvenliği ve organik tarım, mimari uygulamalar ve yerleşke planlama bulunmaktadır. Bunların yanı sıra çevre eğitimi, tohum bankaları oluşturma, tıbbi bitkiler, geleneksel botanik bilimi, deneysel eğitim yöntemleri, felsefe, alternatif tıp ve iyileştirme yöntemleri üzerinde bilhassa durulmaktadır. Auroville'de bulunan ormancılık grubu, arazi restorasyonu üzerinde güzel çalışmalar gerçekleştirmektedir ve geniş bir katılım kitlesine sahip bir eğitim merkezi haline gelmiştir (Mueller, 2012).

Çizelge 1. Auroville ekoköyünün arazi kullanımları

\begin{tabular}{|c|c|c|c|}
\hline \multicolumn{2}{|c|}{ Arazi kullanımı } & Büyüklük (ha) & Yüzde \\
\hline \multirow{9}{*}{$\frac{\frac{c}{\sqrt{0}}}{\frac{\pi}{\pi}}$} & Konut & & 40.9 \\
\hline & a) Köy yerleşimleri & 20 & \\
\hline & b) Auroville toplulukları & 75 & \\
\hline & Ticari & 19 & 8.2 \\
\hline & İmalat \& ekonomik aktiviteler & 10 & 4.3 \\
\hline & $\begin{array}{l}\text { Kamusal \& Yarı Kamusal Alanlar (barış meydanı, bahçeler ve yönetim } \\
\text { alanları) }\end{array}$ & 65 & 28 \\
\hline & Yollar & 30 & 13 \\
\hline & Rekreasyonel kullanımlar & 13 & 5.6 \\
\hline & Ara toplam & 232 & 100 \\
\hline & Yenilenmiş arazi & 598 & 34.5 \\
\hline & \multicolumn{2}{|l|}{ Zirai kullanım } & 57.2 \\
\hline & Zirai \& ilgili araştırmalar & 50 & \\
\hline \multirow{5}{*}{$\begin{array}{c}\frac{5}{\frac{5}{\pi}} \\
\frac{\pi}{\sqrt{0}} \\
\text { Toplam } \\
\text { Toplam }\end{array}$} & b) Tarım & 940 & \\
\hline & Islak alan & 45 & 2.6 \\
\hline & Kanyon, atık alanı ve diğer alanlar & 98 & 5.7 \\
\hline & \multirow[t]{2}{*}{ Ara toplam } & 1731 & 100 \\
\hline & & 1963 & \\
\hline
\end{tabular}

\section{Crystal Waters}

Crystal Waters Ekoköyü 1989 yılında, 650 dönüm çalılık bir arazide, Mary Nehri kıyısında, Maleny ve Woodford şehirlerine yaklaşık 26 km uzaklıkta tesis edilmiştir. Yerleşke permakültür ilkeleri doğrultusunda tasarlanmış olup özel konutlar ve ortak konut projeleri içermektedir. Nüfusu 200'ü geçmiştir. Ekoköy, yabani hayata açık bir yapıya sahiptir. Kangurular ve birçok kuş, sürüngen türleri yerleşke içinde istediği gibi dolaşabilmektedir. Ekoköydeki "No cats \& dogs" uygulamasının bu zenginliği sağladığı savunulmaktadır. Crystal Waters permakültür tasarımı, çevre restorasyonu ve topluluk çalışmaları ile ilgili eğitimleriyle ünlüdür. UN - Habitat Ödülü'nü alan bu ekoköy, çok çeşitli şekillerde bina yapım teknikleri geliştirmiştir. Ekoköyün en önemli gelir kaynakları arasında, bahsi geçen konularda verilen eğitimler yer almaktadır.
GEN'in resmi internet sitesinde de duyurulan permakültür ile ilgili eğitimlerin çoğu Crystal Waters'da gerçekleştirilmektedir (Crystal Waters, 2018). Ayrıca ekoköyün resmi internet sitesinde Permakültürün tanımı, ilkeleri, etik temelleri ile ilgili bilgiler de verilmektedir.

Crystal Waters ekoköyü sakinlerinden Max O. Lindegger, dünyaca tanınan sürdürülebilir sistem ve ekolojik yerleşke tasarımcısıdır. Sürdürülebilir sistemler konusunda aranan ve saygı duyulan bir eğitmendir. Sürdürülebilir yaşamanın zorluğuna karşın uygulanabilir, işler çözümler tasarlama ve uygulama konusunda 30 yıllık deneyimi vardır ve bu alanda liderlik etmiştir. Çevre, ekoloji, sürdürülebilirlik, permakültür ve ekolojik köy tasarımı konusunda danışmanlık yapmaktadır. Lindegger, Küresel Ekoköyler Ağı GEN-Asya ve Okyanusya'nın kurucusu ve yöneticisidir. Son 15 yıldır, ekoköy hareketinde etkin olarak yer almış, 
önderlik etmiştir. Birleşmiş Milletler onaylı Ekoköy Tasarım Eğitimi (Ecovillage Design Education-EDE) müfredatının geliştirilmesinde yer almıştır ve eğitmenliğini yapmaktadır. Lindegger'in tasarım felsefesinin esas ilkesi şudur: "Sürdürülebilir sistemler teknolojinin getirdiği yeniliklerden faydalanmakla beraber her şeyden önce bulundukları çevreye uymalıdırlar. Bu sebeple, yerel kültüre ve alışkanlıklara, yerel kaynakları kullanmaya, yerel halka ve bölgeye fayda sağlamaya büyük önem verir. Yaptığı tasarımlar, içinde bulunduğu çevreye çok duyarlıdır. Bu da uzun vadede projelere başarı sağlar". Lindegger'in tasarladığı ve kurulmasında liderlik ettiği Avustralya'daki Crystal Waters Ekoköyü, Birleşmiş Milletler İnsan Yerleşimleri Merkezi (UN Habitat Best Practice) tarafından En İyi Uygulama Örneği olarak gösterilmiştir. Lindegger, bugüne kadar Güney Afrika, Sri Lanka, Fiji, Brezilya, Meksika, Portekiz, Avustralya ve Yeni Zelanda'da eğitimler vermiş ve sayısız projeye danışmanlık yapmıştır. Türkiye'de, 1997 yılında Mete Hacaloğlu tarafından düzenlenen ilk permakültür çalıştayında da eğitmenlik yapmıştır. 2010'un Haziran ayında da İzmir'de gerçekleştirilen yedi günlük permakültür eğitiminde ikinci kez Türkiye'de bulunmuştur. Yayınları arasında, The Best of Permaculture (Nascimanere) kitabı en çok bilinenidir. Ayrıca International Permaculture Journal'ın editörlerinden biridir. Yaşamını sürdürdüğü Crystal Waters Ekoköyü'nde Ekolojik Çözümler (Ecological Solutions) adlı bir şirket yönetmektedir. Lindegger, sürdürülebilir topluluklar geliştirmek konusundaki üstün başarıları sebebiyle Avustralya Başbakanı tarafından Yüzüncüyıl madalyası ile şereflendirilmiştir. Sürdürülebilir tarım konusundaki başarıları sebebiyle de 2004 yılında Sunshine Coast Environmental Council Ödülü'nü kazanmıştır.

\section{Ecoovila}

Ecoovila, Brezilya'nın Porto Alegre şehrinin ortasında bulunan küçük bir ekoköydür. Temel hedefi, kent yerleşimleri için çevreyle dost, sosyal yaşamı destekleyen yapı teknikleri geliştirmek ve sergilemektir. Bu ekoköyün ortaya çıkmasında, Brezilya'daki hakim mimari anlayışın ekolojik ve sosyal boyuttaki negatif etkilerinden rahatsızlık duyan sekiz mimar aile rol almıştır (Dawson, 2006). Bu öncü mimarlar, doğayı taklit etmeye ve ondan öğrenmeye dayanan permakültürden ilham alarak, permakültür tasarım ilkelerinin şehir yerleşimlerindeki uygulamaları üzerine çalışmışlardır. Grup üyeleri birikimlerini birleştirerek, 2001 yılında 2,6 hektarlık bir arazi satın almış ve yirmi sekiz aileyi, yani yaklaşık 112 kişiyi barındırabilecek bir yerleşimi permakültür ilkeleri doğrultusunda tasarlamak için harekete geçmiştir.

Bütün evler, enerjisinden faydalanmak için güneşe göre konumlandırılmıştır. Termal kütleyi, yani gün içinde emilen ısının serin gecelerde eve geri yayılmasını en üst seviyeye çıkarmak için şömineli bir merkezi ısıtma sistemi tasarlanmıştır. Sıcak su güneş panelleri aracılığıyla elde edilmektedir. Nadir olarak kullanılan bir gazlı ısıtma sistemi de mevcuttur. Porto Alegre'deki evlerin aksine, ekoköydeki konutlarda klima bulunmamaktadır. Evler yer altı bölmeleriyle ve yüzeydeki kanallardan geçen hava akımı ile soğutulmaktadır. Yemeklik otları, baharatları ve asma bitkilerini yetiştirebilmek için de bu yenilikçi sistemden faydalanılmaktadır. Yazın sıcak günlerinde evlerin serin kalmasını sağlayan ve Brezilya'da bir ilk olan çim çatılar, aynı zamanda estetik görünüşleri için de tercih edilmiştir (Böhm ve ark., 2015).

Ecoovila, kentsel ekoköyler sınıfında değerlendirilen bir yerleşkedir. Kent baskısı içinde bu işi başarabilmiş olması nedeniyle CASA'ya (Güney Amerika Ekoköy Ağı) üye en önemli ekoköylerdendir. Ecoovila ile ilgili dokümanların çoğunun Portekizce olması ve resmi internet sitesinde Portekizce'den başka bir opsiyonunun olmaması nedeniyle sadece Böhm ve Dawson'un İngilizce yayınları kaynak olarak alınabilmiştir.

\section{EVI - Ecovillage at Ithaca}

Ithaca Ekoköyü, New York'a ve Kanada sınırına oldukça yakındır. New York gibi bir metropolün yakınında olması nedeniyle kentsel ekoköyler sınıfında değerlendirilmektedir. 2015 itibariyle resmi internet sitelerinde belirtildiği üzere 175 dönümlük arazide, 75 ev ve 175 kişinin yaşadığı ufak sayılabilecek bir ekoköydür. Güncel olarak üç konut bölgesine sahip ekoköyde üçüncü konut bölgesi de inşa halindedir. FroG, SoNG ve TREE isimleri verilen bu konut bölgeleri, dünyanın en büyük co-housing yerleşkesi konumundadır. 175 dönüm arazinin \% 80'den fazlası yeşil alan olarak planlanmıştır (EVI, 2018).

EVI'de ekolojik veriler titizlikle incelenmiştir. Yeşil binalar, güneş enerjisinin kullanımı, paylaşmanın önemi ve ekolojik ayak izi konusunda resmi internet sitelerinde de geniş açıklamalara yer verilmiştir. Ekoköyün kışları soğuk geçen bir coğrafyada bulunması nedeniyle, güneşi en iyi şekilde kullanmayı ilke edinen ekoköy sakinleri, bu konuda yaptıkları çalışmalara Passive Solar Design ismini vermişlerdir. Binaların güney cephelerinde geniş pencereler ve camdan duvarlar oluşturup, kuzey cephedeki pencereleri sadece ışı ihtiyacını karşılayacak büyüklükte tasarlamaktadırlar. Her mahalle farklı dönemlerde inşa edildiği için evlerde farklılıklar gözlenebilmektedir. Ancak her bir mahalle, döneminin en yeni teknolojileri kullanılarak inşa edilmiştir.

EVI'de yaşayan peyzaj mimarı Rick Manning ile internet aracılığıyla yazılı görüşmeler yapılmıştır. Manning, özellikle TREE mahallesinde başarılı çalışmalar yapıldığından bahsetmiştir. Rick Manning ve Cornell Üniversitesi'nden öğretim üyesi Michele Palmer, Landscape Architecture Foundation (LAF - Peyzaj Mimarlığı Vakfı) tarafından görevlendirilerek TREE mahallesi üzerinde sürdürülebilir peyzaj ilkeleri gözetilerek bir alan çalışması yapılmıştır. İstilacı Türler (Invasive Species) hakkında çoğu Amerikan eyaleti oldukça hassas davranmaktadır. Birçok eyaletin resmi internet sitesinde, o bölgedeki istilacı ve doğal 
türlerin listesi yayınlanmaktadır. Bu nedenle bu çalışmada da en önemli kalem doğal türlerin bitkilendirmede kullanılması olmuştur. Palmer “Ithaca Ekoköyü'nde özellikle yenilikçi uygulamalar gerçekleştirmedik. Tamamen doğal türlerin kullanımıyla, yöreye zaten alışmış dayanıklı bitkilerle en iyi sürdürülebilir tasarım gerçekleştirilebilir. Çalışmada üzerinde durduğumuz nokta, yaya dostu, yol gelişimini sınırlayan, kümelenmiş mahalleler oluşturmaktı ki bu da ekolojik ayak izini minimumda tutan bir ayrıntıdır." yorumunda bulunmuştur.

\section{Findhorn Ecovillage}

Findhorn Köyü, İngiltere adasının kuzeyinde, deniz kenarında, yüzlerce yıllık taş binalardan oluşan bir İskoç köyüdür. Findhorn Ekoköyü de bu eski köye yürüyerek yaklaşık on dakika uzaklıktadır. Köyün bir uzantısı konumundadır. Findhorn Ekoköyü'nün bulunduğu yerde, gelgit nedeniyle denizin sürekli yükselip alçalması sonucu kum tepeleri bulunmaktaydı ve Findhorn Ekoköyü'nün ilk kurucuları bu arazide karavanlarla yaşamaktaydı. Findhorn Vakfı ise, bölgede karavanlar içinde sürdürülebilir bir yaşam sürme arzusu güden insanların sayısının artmasıyla, zorlu fiziksel şartları biraz olsun düzeltmek ve koordine olmak amacıyla kurulmuştur. Günümüzde ana faaliyetini eğitim programları oluşturmaktadır.

Ekoköyün kuruluşu 1962'ye dek uzanır. Güncel nüfusu yaklaşık 470'tir. 50 farklı ülkeden yılda 14,000 ziyaretçinin uğradığı bu ekoköy, oldukça iyi bir üne sahiptir. 61 ekolojik bina, 4 rüzgar tribünü, çok iyi bir geri dönüşüm sistemine sahiptir. Çok sayıda solar paneller de kullanılmaktadır. Kapsamlı bir geri dönüşüm sistemine sahiptirler. Kendilerine ait bankaları ve para birimleri vardır. Enerjisinin çoğu rüzgâr tribünleri ve güneş enerjisi ile sağlanmaktadır. İlk Uluslararası GEN (Global Ecovillage Network - Küresel Ekoköy Ağı) toplantısı 1995'te Findhorn Ekoköyü'nde gerçekleştirilmiştir. $\mathrm{Bu}$ toplantıda birçok gönüllü sürdürülebilir yerleşim girişimcileri bir araya gelmiş, "Ekoköy" kavramı ilk kez ayrıntılı bir şekilde burada tanımlanmıştır. Bu nedenle, daha önceki tarihlerde başlatılmış tüm girişimler, 1995'ten sonra ekoköy olarak anılmaya başlanmıştır (Findhorn Foundation, 2018).

Ekolojik ayak izi, İngiltere ortalamasının yarısı kadardır. 1998'de yapılan ölçümler sonucunda, BM tarafından endüstrileşmiş dünyada en düşük ekolojik ayak izine sahip yerleşke seçilmiştir. Araştırma GEN-Avrupa ve Sürdürülebilir Gelişim Araştırma Merkezi (Sustainable Development Research Centre - SDRC) işbirliğiyle yapılmıştır. Genel olarak dünyadaki örnekler incelendiğinde, hiçbir ekoköy kendi kendine \% 100 oranında yetebilen bir yapıya sahip değildir. Fakat bu orana en çok yaklaşan ekoköylerin başında Findhorn gelmektedir.

\section{Sieben Linden}

Sieben Linden, Türkçe "Yedi Ihlamur Ağacı" anlamına gelmektedir. Almanya'nın en tanınan ekoköyü olan Sieben Linden'in ilk amacı, bulunulan bölgede çok küçük bir ekolojik iz bırakarak yaşamayı deneyimlemek olmuştur. Projenin öncüleri 1986 yılında toplantılara başlamış, net hedefler koymak için çok yoğun bir şekilde çalışmışlardır
(Ökodorf Sieben Linden, 2018). Proje sürecinde ekolojik inşaat teknikleri ve kaynakların döngüsel dolaşımı gibi, yaşamın tüm alanlarında kendine yeterliliği deneyimlemeyi sağlayan yöntemler tercih edildiğinden, mevcut bir yerleşkeyi iyileştirmek yerine yeni bir yerleşke kurulmasına karar verilmiştir. Yürürlükteki planlama mevzuatı, satın alınabilecek yeterli arazi olmaması ve açı fikirli bir köy bulamamak gibi engeller yüzünden bu süreç uzun ve zorlu geçmiştir. Topluluk üyelerinin yolu eski Doğu Almanya'da bulunan Poppau köyünün belediye başkanıyla 1997 yılında kesiştiğinde, hiç vakit kaybetmeden köyün bitişindeki 22 hektarlık arazi satın alınmış ve proje hayata geçirilmeye başlanmıştır. Berlin ve Hannover'in arasında kalan Almanya'nın bu bölgesinde geçerli olan ucuz arsa fiyatlarından yararlandılarsa da, arazinin satın alınması tüm üyelerin katkısı ile mümkün olmuştur (Dawson 2006). Günümüzde Sieben Linden'ın 47,5 hektarı orman, 26 hektarı bahçe ve tarla, 9 hektarı da binalar, meydan ve yollar olmak üzere toplam 82,5 hektar arazisi vardır (Ökodorf Sieben Linden, 2018).

Topluluk kuruluşunu takip eden altı yıl içinde hızla büyüyerek nüfusunu 30'dan 100'e çıkarmıştır (Dawson 2006). Günümüzde ise yaklaşık 100 yetişkin ve 40 çocuğun yaşadığı 140 kişilik bir nüfusa sahiptir. Topluluk, nüfusunun üst seviyesini 300 olarak öngörmektedir (Ökodorf Sieben Linden, 2018).

\section{BedZED}

BedZED, Londra'nın güneyinde, eskiden çöplük olarak değerlendirilen ve ekolojik değeri olmayan bir arazide, konut/ofis konseptine dayalı çarşı, organik kafe/restoran, kreş, sağlık merkezi, spor ve eğlence mekanlarıyla beraber sentezlenmiş, son derece modern bir ekoköy uygulamasıdır. Mekanik konfor sistemlerine gerek bırakmayacak mükemmellikte pasif sistemler ile tasarımın sonucunda fosil tabanlı enerji kullanımının ve emisyonun sıfırlanabilmesinin başarıldığı, yenilenebilir enerjiden en üst düzeyde yararlanabilen, birçok ödül kazanmış, alışılmadık bir mimari çözümdür. Yerleşkede çok yönlü sürdürülebilir tasarım, yapım, işletim stratejisi vasıtasıyla kullanıcı ve çevre sağığı, toprağın arsa olarak etkin kullanımı ve yeşil alanların ekolojik açıdan zenginleştirilmesi, yağmur suyu ve atık su geri kazanımının yanı sıra su israfının önlenmesi, kaynakların tekrar ve/veya dönüştürülerek değerlendirilmesi, atık yönetimi, bisiklet ve toplu taşımanın desteklendiği yeşil ulaşım ve düşük enerjili tasarım ilkeleri uygulanmaktadır (Utkutuğ 2013).

BedZED'in en önemli katkısı, toplu yerleşim çerçevesinde sürdürülebilirlik konseptlerinin maliyet etkin ve uygulanabilir olduğunu ispatlaması yanı sıra ekolojik teknoloji, ürün ve sistem olarak sayısız yenilik getirmesidir. Temel hedefler olan, yerleşilen bölgenin ekolojik olarak geliştirilmesi ve kendine yeterli bir toplu yerleşim yaratılması başarıyla gerçekleştirilmiştir. Hem konutları, hem de yerleşkesi bağlamında kendine yeterlilik hedefine ulaşılmış olmasının yanı sıra; yaratıcı ve ekolojik katkıları ile de çok ses getiren, çok sayıda ödül kazanmış, uzun süre üzerinde konuşulacak, kendinden sonraki toplu yerleşimlere 
örnek olacak öncü bir uygulamadır. Emlak piyasasındaki fiyatları ve tüketici talebi açısından da beklenenin çok üzerinde prim yapmakta oluşu, benzeri uygulamaları devam ettirme hususunda yatırımcı firmaya önemli bir destek yaratmaktadır.

BedZED'in ofisler ve konutlar dahil toplam alanı yaklaşık olarak $2500 \mathrm{~m}^{2 \prime}$ dir ve güncel olarak 82 kişi yaşamaktadır. BedZED ortaya çıkışı itibariyle bahsi geçen diğer ekoköylerden oldukça farklıdır. Tamamen bir şirketin oluşturduğu, geniş bir site niteliğinde olan yerleşimin mantığının, klasik ekoköyleri ortaya çıkaran ekolojik, ekonomik ve sosyal hassasiyet ile uzaktan yakından bir ilgisi yoktur. Ticari temellere dayanan proje hayata geçirildiğinde, Londra'nın göbeğinde yaşayan ve bir ekoköy hayatına yakın bir yaşam sürmek isteyen insanlara hitap etmeye başlamıştır. Klasik bir apartman dairesine göre çok pahalıya satılan konutların bir kısmı boş kalmıştır. BedZED'den ev kiralayan ya da satın alan insanların, diğer ekoköylerde olduğu gibi kuvvetli sosyal bağlar kurmaları, ekoköy döngüsüne yardım etmeleri söz konusu olmamıştır. Çünkü sitenin ekolojik kaygılar doğrultusunda hazırlanan sistemleri, konusunda uzman eleman kadrosu tarafından takip edilmektedir. BedZED'in bu tez kapsamına alınmasının nedeni, dünya çapındaki ekoköy hareketine ilginç bir örnek olarak gösterilebilecek bir konumda olmasıdır. Çeşitli kurumlarca toplam 20 ödüle layık görülmüş bir uygulamadır. Ekoköy hareketinin kusursuz bir örneği olduğu iddia edilemez, fakat ekolojik kaygılarla ilgili uygulamalar konusundaki başarıları nedeniyle bahsinin geçmesi uygun görülmüştür.

\section{Basata Ekoköyü}

Güney Sina'da Taba ve Nuweiba arasında yer alan Basata, dünyanın en iyi beş plajından birine sahip olduğu için turistler arasında popüler bir mekandır. Güney Sina kültürel açıdan özel bir yerdir, çünkü Saladdin Kalesi'nin yanı sıra Saint Catherine Katedrali ve İncil'de bahsi geçen Musa Dağı gibi birçok tarihi eser içermektedir.

Basata, Mısır'daki ilk ekolojik yerleşke girişimidir. 1986 yılında genç İngiliz Şerif El Ghamrawy ve Alman karısı Maria tarafından kurulmuştur. Basata ekoköyü Kızıldeniz'in kıyısında, ardında yüksek dağlarla oldukça güzel bir coğrafyada yer almaktadır. Ziyaretçiler için bir kamp mekanı bulunmaktadır. Su, Nil nehrinin dallarından elde edilmekte ve geri dönüştürülerek tekrar kullanılmaktadır. Enerji üretiminin çoğu da güneş panelleri ile sağlanmaktadır (Basata, 2018).

Basata Nuweiba'daki atık yönetimi projesi için eşsiz bir tetikleyici olmuştur. Atıklar plastik, metal ve kağıt olarak ayrı ayrı toplanmakta ve akabinde geri dönüştürülmektedir. Organik ve organik olmayan atıklar da değerlendirmeye alınmaktadır. Günümüzde Nuweiba yönetimi, Basata sayesinde idaresindeki tüm yerleşimlerde atık yönetimine dikkat etmeye başlamıştır. Özellikle metal, plastik ve kağıt atıkları geri dönüştürmek için Basata da dahil olmak üzere tüm Güney Sina'dan atık toplamaktadır. Bu nedenle Basata, 2003 yılında atık yönetimi projeleri için hükümetten bir ödül kazanmıştır (Basata, 2018).

Basata, ekoturizm mantığıyla işletilmektedir. Yaklaşık 76 ha büyüklükteki arazide maksimum 85 kişi yaşayabilmektedir (Basata, 2018).

\section{TARTIŞMA VE SONUÇ}

Bulgular kısmında bahsedilen, hemen her alanda sürdürülebilirliği sağlamış, başarılı ekoköylerde kişi başına düşen verimli karasal ve ıslak alanlar hesaplanıp Çizelge 2'de verilmiştir. Literatürde genellikle bir yerleşimin kalabalıklığını hesaplamak için aritmetik nüfus yoğunluğu kullanılmaktadır. Aritmetik nüfus yoğunluğu, kişi sayısının mevcut alana bölünmesi ile saptanmaktadır. Ancak o yöntem daha çok kalabalık yerleşimler için tercih edilmektedir. Ekolojik ayak izini bu tarz yerleşkelerde düşüren en önemli etmenlerden biri de zaten kişi başına düşen verimli karasal ve ıslak alanlardır.

Çizelge 2'de belirtilen verilere göre kişi başına düşen en büyük alan $3250 \mathrm{~m}^{2}$ ile Crystal Waters'da bulunmaktadır. Bir başka deyişle, aritmetik nüfus yoğunluğu en az olan ekoköydür. Kişi başına düşen en küçük alan ise 30,4878049 $\mathrm{m}^{2}$ ile BedZED'de görülmektedir. Bunda BedZED'in Londra'nın göbeğinde olmasından mütevellit sınırlı alana sahip olması etkili olmuştur.

$\mathrm{Bu}$ hesaplamalara göre, bu ekoköylerin nüfus ve alan büyüklükleri sabit tutularak kent boyutuna oranlandığında ne kadar arazi gerektiği sonucuna varılabilir. Örneğin Crystal Waters Ekoköyü'nün nüfusu 1.000 .000 olsaydı, yaklaşık

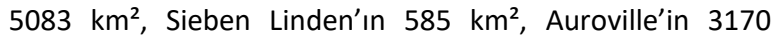
$\mathrm{km}^{2}$ 'lik alana ihtiyacı olacaktı. Bu hesaplamalara göre dünya nüfusu tamamen bu şekilde bir hayat sürmeye kalksa, yeryüzü arazileri yetersiz kalacaktır.

Çizelge 2. Incelenen ekoköylerde kişi başına düşen verimli karasal ve sulak alanlar

\begin{tabular}{llll}
\hline Ekoköyün adı & Güncel nüfusu & Güncel alanı $\left.\mathbf{( m}^{\mathbf{2}}\right)$ & Kişi başına düşen alan $\left(\mathbf{m}^{\mathbf{2}}\right)$ \\
\hline Findhorn & 600 & 121.000 & 201,666667 \\
Sieben Linden & 140 & 82.000 & 585,714286 \\
EVI & 175 & 175.000 & 1000 \\
BedZED & 82 & 2.500 & 30,4878049 \\
Auroville & 1519 & 1963.000 & 1292.29756 \\
Crystal Waters & 200 & 650.000 & 3250 \\
Ecoovila & 112 & 26.000 & 232,142857 \\
Basata & 85 & 44.000 & 517.647059 \\
\hline
\end{tabular}


Dünyanın toplam yüzey alanı $510.072 .000 \mathrm{~km}^{2}$ 'dir. Bunun $148.940 .000 \mathrm{~km}^{2 \prime}$ sini kara, 361.132 .000 km²'sini su yüzeyi oluşturmaktadır (CIA, 2018). Yukarıdaki oranlara göre, nüfusu yaklaşık 6.550.000.000 olan dünyamızın, ekolojik ayak izini zararsız bir seviyede tutabilmek için yeterli arazisi mevcut değildir. Yapılan çalışmalara göre, dünyadaki varlığımızı ona zarar vermeden sürdürebilmemiz için, 2030'a gelindiğinde 2, 2050'ye gelindiğinde ise 2,8 büyüklüğünde dünyaya ihtiyaç duyulacağı öngörülmektedir (WWF, 2012).

Sieben Linden ve Auroville ekoköyleri, kendi internet sitelerinde yerleşkeleri için öngördükleri maksimum nüfusu belirtmişlerdir. Sieben Linden en çok 300 kişinin yaşayabileceği bir yerleşim olduğunu duyurmuştur. Bu durumda Sieben Linden'de kişi başına düşen alan, eğer arazilerini genişletmezlerse $273,3 \mathrm{~m}^{2}$ olacaktır. Auroville ise bu konuda daha iddialı açıklamalar yapmıştır. Halihazırda bir kasaba büyüklüğünde olan Auroville, yine aynı ekolojik hassasiyetlerde bir kent ölçeğine dönüşebileceğini iddia etmektedir. Yaklaşık 50.000 kişilik bir nüfusu, sadece yeni ve verimli arazilere ihtiyaç duyarak aynı ekolojik ayak iziyle kaldırabileceklerini belirtmişlerdir. Fakat spritüel temeller üzerine kurulmuş yerleşkede 50.000 kişinin aynı hassasiyete sahip olamayacağı tartışmaları, bu eylemin gerçekleşebilirliği hususunda araştırmacıları tereddüte düşürmektedir ve bu hedefe asla ulaşılamayacağı düşünülmektedir. Bir ekoköyün kent ölçeğinde uygulanıp uygulanamayacağı tartışmaları burada gündeme gelmiştir.

Sonuç olarak, günümüzde hayatta olan tüm insanlar ekolojik ayakizlerini bir ekoköy başarısıyla düşürebilmek adına, yaban hayatına hiç yer kalmayacak şekilde çöl, kutuplar, ormanlar ve dağ zirveleri dahil olmak üzere dünyadaki tüm karasal alanlara homojen olarak yayılsalar bile, kişi başına düşen alan miktarına bakıldığında bir ekoköyün potansiyelini yakalamak mümkün değildir. Ekoköyler küçük topluluklar için mükemmel bir çözüm önerisi olmakla birlikte, milyonların yaşadığı kentlere entegre edilmesi olası değildir. Yine de, kentlerdeki yoğun nüfusun oluşturduğu baskıyı azaltmak, insanları kırsal bölgelere çekerek doğayla daha net ve güçlü bir ilişki içinde yaşama fırsatı sunmaları bakımından ekoköyler, dünyadaki yaşamın yok olmasını geciktirecek önemli girişimlerin başında gelmektedir. Bu tarz girişimler arttırılmalı, desteklenmeli, teşvik edilmelidir.

\section{KAYNAKLAR}

Auroville (2018) Auroville in brief. Web Sitesi: https://www.auroville.org/categories/12. Erişim Tarihi: 21.12.2018.

Basata, 2018. First Ecovillage in Egypt. Web Sitesi: http://www.basata.com/index.html, Erişim Tarihi: 25.12.2018.

Böhm, S, Bharucha, Z P and Pretty, J (2015) Ecocultures: Blueprints for Sustainable Communities. NY, US.

CIA (2018) Central Intelligence Agency. The World Factbook. Web Sitesi: https://www.cia.gov/library/publications/the-worldfactbook/geos/xx.html. Erişim Tarihi: 25.12.2018.

Crystal Waters (2018) Crystal Waters Ecovillage. Web Sitesi: https://crystalwaters.org.au/accomodation/propertie s-for-sale/. Erişim Tarihi: 14.11.2018.

Dawson, J (2006) Ecovillages: New Frontiers for Sustainability.Londra: Green Books Press, 96s.

EVI (2018) Ecovillage at Ithaca. Web Sitesi: www.ecovillageithaca.org. Erişim Tarihi: 21.12.2018.

Findhorn Foundation (2018) About us. Web Sitesi: https://www.findhorn.org/about-us/. Erişim Tarihi: 23.11.2018.

Jackson, R (2004). The Ecovillage Movement. Permaculture Magazine No: 40.

Maslin, M (2011) Küresel Isınma (Türkçesi: Sinem Gül). Dost Yayınevi, Kültür Kitaplığı: 104, Bilim:4. Ankara, 200s.

Mueller, M (2012) Global Ecovillage Network - Living And Learning Centres. Web Adresi: http://gen.ecovillage.org/sites/default/files/files/Il_si ngle.pdf. Erişim Tarihi: 01.11.2018.

Ökodorf Sieben Linden (2018) History. Web sitesi: https://siebenlinden.org/en/ecovillage-2/history/. Erişim Tarihi: 26.12.2018.

Utkutuğ, G (2013) Sürdürülebilir Bir Gelecek İçin Mimarlık: Ekolojik Mimarlığın Ulaştığı Son Nokta, BedZED. TTMD - Türk Tesisat Mühendisleri Derneği Dergisi, Sayı: 36.

WWF (2012) Türkiye'nin Ekolojik Ayakizi Raporu. Web Sitesi:

https://www.footprintnetwork.org/content/images/a rticle_uploads/Turkey_Ecological_FFootprin_Report_ Turkish.pdf. Erişim Tarihi: 12.10.2015. 
